\title{
PENGARUH GAYA MENGAJAR DAN KEMAMPUAN AWAL TERHADAP HASIL BELAJAR KETERAMPILAN SEPAKBOLA
}

\author{
Mochamad Iman Setiawahyu \\ Universitas 17 Agustus 1945 Cirebon \\ email: moch.iman@gmail.com
}

\begin{abstract}
Abstrak
Tujuan penelitian ini untuk menggetahui perbedaan pengaruh antara metode gaya mengajar dan kemampuan awal terhadap hasil belajar keterampilan sepakbola yang memiliki tingkat kemampuan awal tinggi dan rendah. Penelitian ini juga ingin mengetahui adanya interaksi antara gaya mengajar dan kemampuan awal. Metode penelitian menggunakan metode eksperimen dengan desain faktorial $2 \times 2$ dengan sampel 40 siswa ekstrakulikuler klas VII di SMP Negeri 9 Bandung. Teknik pengambilan sampel menggunakan teknik rendom assignment. Sampel dibagi kedalam empat kelompok, yang masing-masing kelompok terdiri atas 10 siswa. Instrumen penelitian menggunakan alat ukur tes kecakapan dan keretampilan bermain sepakbola dari Nurhasan dan Vernon yang di modivikasi jarak dan ukuranya. Teknik analisis data yang digunakan adalah Analisis Variansi (ANOVA) yang dilanjutkan dengan Uji Tukey pada taraf signifikansi $\propto 0,05$. Hasil penelitian bahwa (1) Ternyata skor rata-rata keterampilan sepakbola yang diajar dengan gaya mengajar resiprokal lebih tinggi dari rata-rata yang diajar dengan gaya mengajar komando $\square A l=202.68>\square A 2=186.94$. (2) Adanya interaksi yang signifikan karena kedua kelompok tingkat kemampuan awal yang diajar dengan menggunakan gaya mengajar resiprokal dan komando. (3) Ternyata skor rata-rata keterampilan awal tinggi yang diajar dengan gaya mengajar resiprokal lebih kecil dari rata-rata yang diajar dengan gaya mengajar komando $\square A 1 B 1=206.82<\square A 2 B 1=215.10$. (4) Ternyata skor rata-rata keterampilan awal rendah yang diajar dengan gaya mengajar resiprokal lebih tinggi dari ratarata yang diajar dengan gaya mengajar komando $\square A 1 B 2=202.68>\square A 2 B 2=186.94$.
\end{abstract}

Kata Kunci: gaya mengajar, kemampuan awal, hasil belajar.

\begin{abstract}
The purpose of this research is to know the difference of influence between the teaching style method and the early ability to learn soccer skills with high and low initial ability level. This study also wanted to know the interaction between teaching style and initial ability. The research method used experimental method with $2 \times 2$ factorial design with a sample of 40 students extracurricular class VII in SMP Negeri 9 Bandung. The sampling technique uses rendom assignment technique. The sample is divided into four groups, each group consists of 10 students. The research instrument used a measuring tool of skill test and football playing skill from Nurhasan and Vernon which modified the distance and size. Data analysis technique used is Analysis of Variance (ANOVA) followed by Tukey Test at significance level a 0,05. The results showed that (1) It turns out that the average score of soccer skills taught with a reciprocal teaching style is higher than the average taught with the command teaching style $\square A 1=202.68>\square A 2=186.94$. (2) There was significant interaction because both groups of initial skill levels were taught by using reciprocal teaching style and command. (3) It turns out that the average score of high initial skills taught with reciprocal teaching style is smaller than
\end{abstract}


the average taught with the command teaching style $\square A l B 1=206.82<\square A 2 B 1=215.10$. (4) It turns out that the low average initial skill score taught with a reciprocal teaching style is higher than the average taught with the command teaching style $\square A 1 B 2=202.68>\square A 2 B 2=186.94$.

Keywords: teaching style, initial ability, and learning outcomes.

(C) 2017 STKIP Muhammadiyah Kuningan 


\section{PENDAHULUAN}

Pada saat ini permainan sepakbola tidak hanya menjadi olahraga prestasi, melainkan pengisi waktu luang dan kegiatan extra di sekolah berorentasi kepada tujuan, dimulai dengan tujuan rekreatif, kesehatan, pendidikan dan prestasi. Seperti yang di kemukakan Lutan (1988: 9) bahwa “ Olahraga tumbuh dan berkembang dalam berbagai bentuk dengan cara pelaksanaan wilayah kegiatan olahraga dibagi menjadi empat bagian, yaitu olahraga kompetitif, olahraga profesional, olahraga rekreatif, dan olahraga pendidikan.

Sepakbola merupakan olahragaketerampilan yang kompek meskipun begitu, menurut Harsono (1992: 100)“ada empat aspek latihan yang perlu diperhatikan dan dilatih secara seksama oleh atlet, yaitu latihan fisik, latihan teknik, latihan taktik dan mental". Dalam hal ini penulis akan menekankan pada aspek teknik dasar keterampilan sepakbola. Menurut pendapat Utami Munandar (Abuy, 2002: 4) yaitu: "Setiap orang mempunyai potensi yang berbeda-beda dan oleh karenanya membutuhkan layanan pendidikan yang berbeda pula. Pendidikan bertanggung jawab untuk memandu (artinya mengidentifikasi dan membina) dan memupuk (artinya mengembangkan dan meningkatkan) potensi-potensi tersebut secara utuh".

Belajar menurut Hilgard dalam Nasution (1987: 39) " Leaming is the process by which an activity originates or is changed through training procedures (Whether in the laboratory or in the natural environment) as distinguished from changes by factors not atributable to training. Belajar merupakan sutu proses aktivitas seseorang yang pada dasarnya merupakan cerminan suatu kegiatan, apakah dalam laboratorium atau lingkungan alamiah yang menyebabkan perubahan akibat melakukan tugas tertentu, perubahan prilaku yang terjadi baru dapat dikatakan belajar apabila diakibatkan oleh proses latihan. Dalam hal ini Lutan (1988: 390) mengemukakan bahwa, "Efektifitas guru dalam menghasilkan perubahan prilaku atas hasil belajar tergantung pada kemampuannya untuk menjabarkan waktu kelas ke dalam waktu yang termanfatkan untuk berlatih dan waktu untuk menyampaikan informasi kepada siswa". Lebih lanjut Suherman (1996: 2) menjelaskan bahwa, "Merencanakan, menjelaskan, ceramah, bertanya, mengelola kelas dan memberikan umpan balik merupakan beberapa keterampilan yang harus dimiliki seorang guru untuk mencapai tujuan mengajarnya".

Gaya mengajar pendidikan jasmani menurut Mosston dan Ashworth (1994: 11) yaitu, "a) Command Style, b) Practice Style, c) Reciprocal Style, d) Self-Check Style, e) Inclucion Style, f) Guided-Discovery Style, g) Divergent Style, dan h) Individual Program-Leamer's Design". Untuk lebih 
jelasnya uraian gaya mengajar tersebut adalah sebagai berikut:

Command Style atau pengajaran dengan gaya komando menurut Mosston dan Ashworth (1994: 14) guru yang paling dominan dalam membuat seluruh keputusan kegiatan belajar mengajar. Peran siswa mentaati semua perintah dan petunjuk yang diberikan oleh gurunya. Setiap gerakan yang dilakukan oleh siswa selalu mengikuti contoh-contoh yang diberikan oleh guru dengan kata lain gaya komando merupakan gaya mengajar yang paling bergantung pada guru, yaitu ditandai dengan penjelasan tentang teknik, demonstrasi, latihan, dan kemudian siswa mencontohkan gerakan yang dilakukan oleh gurunya.

Reciprocal Style atau gaya timbal balik Mosston dan Ashworth (1994: 65); dalam pelaksanaan pembelajarannya dilakukan secara berpasangan, siswa mempunyai peranan masing-masing, yaitu seorang berperan sebagai pelaku dan lainnya berperan sebagai pengamat, yang membenarkan umpan balik berdasarkan kiteria yang telah ditetapkan gurunya. Dengan kata lain pembelajaran yang dalam pendekatan mengajarnya memberikan suatu tugas kepada siswa untuk berpasangan dalam belajar, secara bergantian bertukar peran sebagai pengamat dalam memberikan penilaian formatif atau feedback pasangannya, mengacu kepada tujuan instruksional yang telah ditetapkan oleh guru. Dalam sepakbola guru memberikan instruksi diawal sebelum kegiatan belajar mengajar berlangsung, lalu dalam perakteknya siswa mengajar satu sama lain dengan saling bertukar peran antara pelakau dan pengamat tentang gerakan yang telah diinstruksikan gurunya, dan kemudian diakhir pelajaran siswa saling memberikan umpanbalik tentang teknik yang telah dipelajari.

\section{METODE}

Penelitian ini menggunakan metode eksperimen pretest-posttest. Dengan desain yang digunakan yaitu faktorial $2 \times 2$. Digunakan desain faktorial tersebut karena eksperimen dalam penelitian ini melibatkan dua variabel independen (Metode gaya mengajar, dan kemampuan awal) yang masing-masing terdiri dari dua taraf. Metode gaya mengajar (resiprokal dan komando) dan kemampuan awal (tinggi dan rendah).

Populasinya adalah siswa SMP Negeri 9 Bandung kelas VII (Usia 12-13) yang mengikuti extrakulikuler sepakbola sebanyak 60 orang siswa. Teknik pengambilan sampel yaitu teknik rendom assignment ditetapkan 40 orang dari 60 siswa diambil sebagai sampel, yang merupakan ciri pokok yang dibutuhan peneliti. Selanjutnya terhadap 40 orang siswa tersebut dilakukan tes pendahuluan, yaitu untuk memper oleh tingkat keterampilan awal tinggi dan rendah. Setelah mendapatkan data tersebut, peneliti membuat daftar ranking dari pertama 
hingga akhir dan mendata dari yang tertinggi dan terrendah.

Kemudian penulis membagi ke 40 orang tersebut berdasarkan pendapat Verducci (1980: 176), yaitu diambil 50\% kelompok tinggi dan 50\% kelompok rendah. Dengan demikian dalam setiap kelompok gaya mengajar terdapat 20 orang siswa yang mempunyai kemampuan awal tinggi dan rendah. Selanjutnya dibagi kelompok ditentukan perlakuan yang menggunakan gaya mengajar resiprokal 10 orang, yaitu dua kelompok (tinggi dan rendah), dan untuk gaya mengajar komando 10 orang, yaitu dua kelompok (tinggi dan rendah). mengdistribusikan siswa-siswanya dengan cara dari hasil rengking yang bernomor ganjil diajar dengan gaya resiprokal dan yang bernomor genap diajar dengan gaya komando.

\section{HASIL PENELITIAN}

Pada bagian ini disajikan nilai rata-rata, simpangan baku (standar deviasi), dan sekor terrendah dan sekor tertinggi. Deskripsi data hasil pretest dan posttest bisa dilihat pada Tabel 1 dan 2 dihalaman beriku.

Tabel 1 Hasil Uji Hipotesis Gaya Mengajar Terhadap Hasil Belajar Keterampilan Sepakbola

Tests of Between- subjects Effects

\begin{tabular}{|l|l|l|l|l|c|c|}
\hline \multicolumn{2}{|l|}{ Dependent Variable:Ket_S_Bola } & Type III Sum & \multirow{2}{*}{ df } & Mean & \multirow{2}{*}{ F } & Sig \\
\cline { 3 - 5 } \multicolumn{2}{|c|}{ Source } & of Squares & & Square & & \\
\hline Gaya_Mengajar & Hypothesis & 84.419 & 1 & 84.419 & \multirow{2}{*}{4.931} & \multirow{2}{*}{0.269} \\
\hline & Error & 17.122 & 1 & 17.122 & & \\
\hline
\end{tabular}

\section{Hipotesis 1}

Berdasarkan hasil perhitungsn analisis varians mengenai perbedaan gaya mengajar terhadap hasil belajar keterampilan sepakbola, secara keseluruhan seperti terlihat pada Tabel 4.5, diketahui bahwa nilai $\mathrm{F}$ hitung adalah 4,931 dengan probabilitas (Sig.) 0,269. Karena probabilitas (Sig.) 0,269 $>0,05$, maka dapat disimpulkan bahwa $\mathrm{H}_{0}$ diterima, karna nilai probabilitas signifikansinya lebih besar dari $\alpha 0,05$ yang menyatakan bahwa gaya mengajar bisa digunakan untuk memprediksi antara gaya mengajar resiprokal dan komando.

\section{Hipotesis 2}

Berdasarkan hasil perhitungan analisis varians mengenai pengaruh interaksi antara gaya mengajar dengan kemampuan awal terhadap hasil belajar keterampilan sepakbola, seperti pada Tabel 2. 
Tabel 2. Hasil Uji Hipotesis Gaya Mengajar Terhadap Kemampuan awal

Tests of Between- subjects Effects

\begin{tabular}{|l|l|l|c|l|c|c|}
\hline \multicolumn{2}{|l|}{ Dependent Variable:Ket_S_Bola } \\
\hline \multirow{2}{*}{ Source } & $\begin{array}{l}\text { Type III } \\
\text { Sum }\end{array}$ & \multirow{2}{*}{ df } & Mean & \multirow{2}{*}{ F } & \multirow{2}{*}{ Sig } \\
\cline { 3 - 5 } \cline { 5 - 6 } & of Squares & & Square & & \multirow{2}{*}{0.144} & 0.706 \\
\hline Gaya_Mengajar* & Hypothesis & 17.122 & 1 & 17.122 & \\
\hline Kemampuan & Error & 4.274 .368 & 36 & 118.732 & & \\
\hline
\end{tabular}

Diketahui (gaya mengajar kemampuan awal) nilai sig. 0,706 > 0,05 maka $\mathrm{H}_{0}$ : $\mathrm{B} 1$ = B1 ditolak. Artinya Tidak terdapat interaksi antara gaya mengajar dengan kemampuan awal terhadap hasil belajar keterampilan sepakbola, sehingga hipotesis Penelitian (H1) : B1 $>$ B2 yang diterima. Berdasarkan penghitungan ternyata skor rata-rata keterampilan sepakbola yang menggunakan gaya mengajar resiprokal adalah sebesar 10,62 untuk kelompok siswa yang memiliki keterampilan tinggi, dan 23,46 untuk kelompok siswa yang memiliki keterampilan rendah. Kemudian skor rata-rata keterampilan sepakbola yang menggunakan gaya mengajar komando adalah sebesar 14,83 untuk kelompok siswa yang memiliki keterampilan tinggi, dan 25,06 untuk kelompok siswa yang memiliki keterampilan rendah. Dengan demikian dapat disimpulkan bahwa terjadi interaksi antara gaya mengajar dengan kemampuan awal terhadap hasil belajar keterampilan sepakbola. Bisa dilihat di Tabel 3.

Tabel 3 Lanjutan Uji Tukey Keterampilan Sepakbola Tukey HSD ${ }^{a}$

\begin{tabular}{|c|c|c|c|}
\hline \multirow{2}{*}{ Kelompok } & \multirow{2}{*}{} & \multicolumn{2}{|c|}{ Subset for alpha $=0.05$} \\
\cline { 3 - 4 } & $\mathrm{N}$ & 1 & 2 \\
\hline Resiprokal Tinggi & 10 & 10.62 & \\
Komando Tinggi & 10 & 14.83 & 14.83 \\
Resiprokal Rendah & 10 & 23.46 & 23.46 \\
Komando Rendah & 10 & & 25.06 \\
Sig. & & .057 & .173 \\
\hline
\end{tabular}

Means for groups in homogeneous subsets are displayed.

a. Uses Harmonic Mean Sample Size $=10.000$.

Untuk mengetahui ada atau tidaknya interaksi antara gaya mengajar dan 
kemampuan awal terhadap hasil belajar

pada Grafik 1.

keterampilan sepakbola dapat dilihat

Grafik 1. Interaksi Antara Gaya Menggajar Dan Kemampuan Awal

Terhadap Hasil Belajar Keterampilan Sepakbola

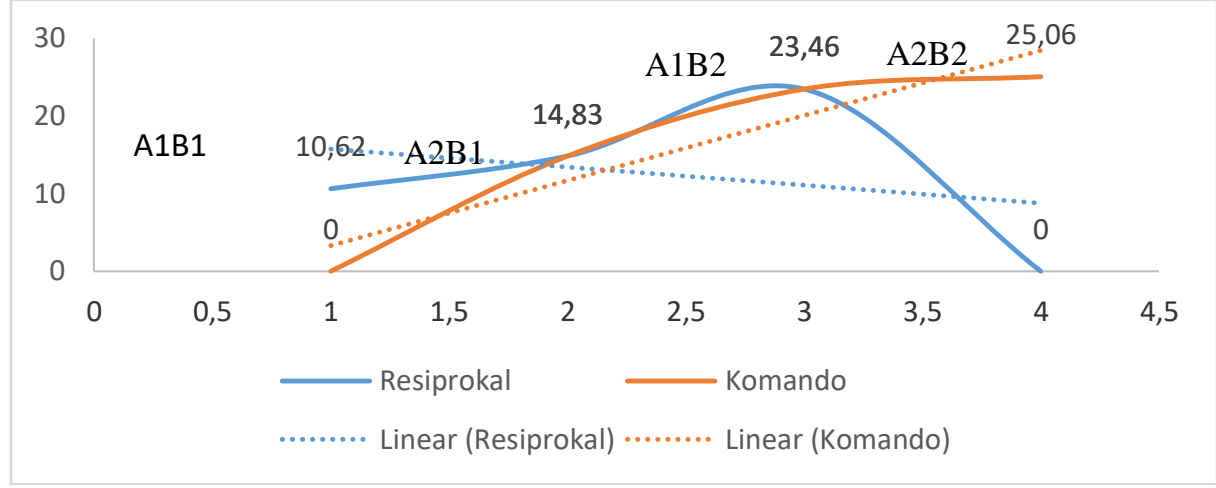

Keterangan :

$\mu \mathrm{A} 1 \mathrm{~B} 1=$ Kelompok siswa yang memiliki tingkat kemampuan awal tinggi yang diajar dengan gaya mengajar resiprokal. $\mu \mathrm{A} 2 \mathrm{~B} 1=$ Kelompok siswa yang memiliki tingkat kemampuan awal tinggi yang diajar dengan gaya mengajar komando. $\mu \mathrm{A} 1 \mathrm{~B} 2=$ Kelompok siswa yang memiliki tingkat kemampuan awal rendah yang diajar dengan gaya mengajar resiprokal $\mu \mathrm{A} 2 \mathrm{~B} 2=$ Kelompok siswa yang memiliki tingkat kemampuan awal rendah yang diajar dengan gaya mengajar kemando.

\section{Hipotesis 3}

Berdasarkan hasil perhitungsn analisis varians mengenai perbedaan hasil belajar keterampilan sepakbola antara siswa yang diajar melalui gaya mengajar resiprokal dan gaya mengajar komando pada siswa yang memiliki kemampuan awal tinggi, secara keseluruhan seperti terlihat pada Tabel 4.

Tabel 4

Hasil Uji Hipotesis Gaya Mengajar Yang Memiliki Kemampuan Awal Tinggi

Multiple Comparisons

Ket_S_Bola

Tukey HSD

\begin{tabular}{|c|c|c|c|c|c|c|}
\hline \multirow{2}{*}{$\begin{array}{c}\text { (I) } \\
\text { Kelompok }\end{array}$} & \multirow{2}{*}{$\begin{array}{c}(\mathrm{J}) \\
\text { Kelompok }\end{array}$} & $\begin{array}{c}\text { Mean } \\
\text { Difference }\end{array}$ & \multirow{2}{*}{ Std.Error } & \multirow{2}{*}{ Sig } & \multicolumn{2}{|c|}{$\begin{array}{l}\text { 95\% Confidence } \\
\text { Interval }\end{array}$} \\
\hline & & $(\mathrm{I}-\mathrm{J})$ & & & $\begin{array}{l}\text { Lower } \\
\text { Bound }\end{array}$ & $\begin{array}{l}\text { Upper } \\
\text { Bound }\end{array}$ \\
\hline $\begin{array}{c}\text { Resiprokal } \\
\text { Tinggi }\end{array}$ & $\begin{array}{l}\text { Komando } \\
\text { Tinggi }\end{array}$ & -4.214 & 4.873 & 0.823 & -1.733 & 891 \\
\hline
\end{tabular}


Ternyata diketahui gaya mengajar nilai sig. 0,823 >0,05 maka $\mathrm{H}_{0}$ diterima. Artinya Tidak terdapat keterampilan sepakbola antara siswa yang diajar melalui gaya mengajar resiprokal dan gaya mengajar komando yang memiliki kemampuan awal tinggi. Berdasarkan hasil penghitungan ternyata skor rata-rata keterampilan awal tinggi yang diajar dengan gaya mengajar resiprokal lebih kecil dari rata-rata yang diajar dengan gaya mengajar komando $\square \mathrm{AlBl}=206.82<$ perbedaan hasil belajar

$\mathrm{A} 2 \mathrm{~B} 1=215.10$. Hal ini berarti hipotesis penelitian yang menyatakan bahwa terdapat perbedaan pengaruh antara gaya mengajar resiprokal dan gaya mengajar komando telah teruji.

\section{Hipotesis 4}

Berdasarkan hasil perhitungan analisis varians mengenai perbedaan hasil belajar keterampilan sepakbola pada siswa yang memiliki kemampuan awal rendah antara yang menggunakan gaya mengajar resiprokal dan yang menggunakan gaya mengajar komando, seperti pada Tabel 5 .

Tabel 5

Hasil Uji Hipotesis Gaya Mengajar Yang Memiliki Kemampuan Awal Rendah Multiple Comparisons

Ket_S_Bola

Tukey HSD

\begin{tabular}{|c|c|c|c|c|c|c|}
\hline \multirow{2}{*}{$(\mathrm{I})$ Kelompok } & \multirow{2}{*}{$\begin{array}{c}\text { Mean } \\
\text { Kelompok }\end{array}$} & Difference & \multirow{2}{*}{ Std.Error } & \multirow{2}{*}{ Sig } & \multicolumn{2}{|c|}{$\begin{array}{c}\text { 95\% Confidence } \\
\text { Interval }\end{array}$} \\
\cline { 3 - 7 } & $(\mathrm{I}-\mathrm{J})$ & & $\begin{array}{c}\text { Lower } \\
\text { Bound }\end{array}$ & $\begin{array}{c}\text { Upper } \\
\text { Bound }\end{array}$ \\
\hline $\begin{array}{c}\text { Resiprokal } \\
\text { Rendah }\end{array}$ & $\begin{array}{c}\text { Komando } \\
\text { Rendah }\end{array}$ & -1.597 & 4.873 & 0.988 & -14.721 & 11.527 \\
\hline
\end{tabular}

Diketahui gaya mengajar nilai sig. tinggi dari rata-rata yang diajar dengan gaya $0,988>0,05$ maka $\mathrm{H}_{0}$ diterima. Artinya mengajar komando $\square$ A1B2 $=202.68>\square$ Tidak terdapat perbedaan hasil belajar keterampilan sepakbola antara siswa yang diajar melalui gaya mengajar resiprokal dan gaya mengajar komando yang memiliki kemampuan awal rendah. Berdasarkan hasil penghitungan ternyata skor rata-rata keterampilan awal rendah yang diajar dengan gaya mengajar resiprokal lebih
$\mathrm{A} 2 \mathrm{~B} 2=186.94$. Hal ini berarti hipotesis penelitian yang menyatakan bahwa terdapat perbedaan pengaruh antara gaya mengajar resiprokal dan gaya mengajar komando telah teruji.

Penelitian ini dilakukan untuk mendapatkan jawaban dari pertanyaanpertanyaan penelitian yaitu: 1) Apakah ada 
perbedaan hasil belajar keterampilan sepakbola antara siswa yang diajar melalui gaya mengajar resiprokal dan gaya mengajar komando. 2) Apakah ada pengaruh interaksi antara gaya mengajar dengan kemampuan awal terhadap hasil belajar keterampilan sepakbola. 3) Apakah ada perbedaan hasil belajar keterampilan sepakbola antara siswa yang diajar melalui gaya mengajar resiprokal dan gaya mengajar komando pada siswa yang memiliki kemampuan awal tinggi. 4) Apakah ada perbedaan hasil belajar keterampilan sepakbola antara siswa yang diajar melalui gaya mengajar resiprokal dan gaya mengajar komando pada siswa yang memiliki kemampuan awal rendah. Dari hasil pengolahan dan analisis data yang telah penulis lakukan, diperoleh hasil bahwa;

1) Berdasarkan hasil analisis data penelitian, diperoleh hasil hipotesis penelitian yang menyatakan bahwa terdapat perbedaan hasil belajar antara gaya mengajar resiprokal dan gaya mengajar komando. Hal ini dibuktikan dengan nilai rata-rata hasil belajar melalui gaya menggajar resiprokal lebih baik dari rata-rata gaya menggajar komando. Ini berarti bahwa keterampilan siswa dari gaya mengajar resiprokal terdapat peningkatan lebih baik. Lebih lanjut lagi dijelaskan oleh Mosston dan Ashworth (1994). Para siswa bertanggung jawab untuk mengobservasi penampilan dari teman atau pasangannya dan memberikan umpan balik segera pada setiap kali melakukan gerakan.

2) Oleh karena itu gaya mengajar resiprokal bentuk latihan keterampilan sepakbola lebih menekankan pada fungsi, atrinya produktivitas dalam melakukan penggulangan lebih diutamakan. Selain itu situasi lingkungan belajar yang kondusif yaman sehingga keterampilan siswa lebih efektif pada saat pembelajaran. Oleh karena itu peluang siswa untuk memiliki keterampilan dalam memahami persepsi, desisi, eksekusi dan memberikan umpan balik kepada dirinya lebih terbuka. Pada gaya mengajar komando lebih menekankan kepada bentuk teknik keterampilan sepakbola, gerakan teknik sepakbola diutamakan dari pada fungsi. Latihan dengan gaya komando lebih monoton, sehingga tidak timbul kreativitas dan kurang peka terhadap teknik keterampilan sepakbola yang diberikan oleh guru/pelatih. Berdasarkan temuan secara praktis dari hasil penelitian ini. Ternyata pelaksanaan pembelajaran suatu keterampilan, tidak terkecuali permainan sepakbola yang menggunakan gaya mengajar resiprokal dan gaya mengajar komando memberikan pengaruh yang berbeda 
terhadap hasil belajar keterampilan sepakbola.

3) Pada gaya mengajar komando lebih cocok untuk terapi kesalahan gerakan teknik, hal ini disebabkan cara penyajian materi yang dikontrol secara ketat, mengikuti contoh yang diberikan oleh gurunya. Pendapat tersebut yang dikemukakan supardi dan seba (suntoda 1991:43 sebagai berikut: "Gaya mengajar komando sangat efektif bila ingin membina keseragaman dan keserentakan gerakan dengan bentuk yang diingini guru, mempertinggi disiplin dan kepatuhan. Tidak memerlukan pengetahuan yang banyak dari bahan ajarnya, pengontrolan laju informasi sepenuhnya dikuasai oleh guru".

4) Berdasarkan hasil analisis data penelitian, diperoleh hasil hipotesis penelitian yang menyatakan bahwa terdapat interaksi antara gaya mengajar dengan kemampuan awal terhadap hasil belajar keterampilan sepakbola. Berdasarkan hasil penelitian bahwa keterampilan awal siswa dan gaya mengajar sendiri-sendiri/terpisah mempengaruhi penguasaan hasil belajar, sehingga ada interaksi yang signifikan antata kemampuan awal dan gaya mengajar terhadap hasil belajar keterampilan sepakbola. Mendukung pernyataan ini, Kerlinger (1990: 399) mengemukakan bahwa "interaksi tidak terjadi jika lebih dari satu variabel bebas membawa akibat-akibat terpisah (maineffects) yang signifikan. Selain itu bahwa mendikhotomikan antara dua gaya atau strategi pembelajaran dalam satu rentang proses belajar mengajar hanya akan membingungkan dan mengakibatkan ketidak seimbangan dalam merancang program pendidikan. Terpenting adalah siswa membutuhkan pengalaman dan pengembangan dari seluruh dimensi. Kesimpulan bahwa penggunaan gaya mengajar dalam pembelajaran dapat dilakukan secara bersama-sama, tidak mutlak menggunakan satu gaya dan harus di sesuaikan dengan situasi saat pembelajaran berlangsung.

5) Berdasarkan hasil analisis data penelitian, diperoleh hasil hipotesis penelitian yang menyatakan bahwa terdapat pengaruh gaya mengajar resiprokal dan gaya mengajar komando terhadap hasil belajar kemampuan sepakbola pada siswa yang memiliki keterampilan tinggi. Hal ini dibuktikan dengan nilai rata-rata kemampuan awal tinggi gaya menggajar resiprokal lebih rendah dari rata-rata gaya menggajar komando. Ini berarti bahwa keterampilan siswa dari gaya mengajar resiprokal tidak lebih baik peningkatannya dari pada gaya mengajar komando. Jadi gaya mengajar komando memberikan 
peningkatan yang lebih baik terhadap keterampilan siswa dari pada gaya mengajar resiprokal pada siswa yang memiliki kemampuan awal tinggi.

Bagi siswa yang mempunyai keterampilan awal tinggi bukan merupakan masalah yang besar untuk menguasai materi ajar yang diberikan lebih baik dibandingkan siswa yang kemampuan awalnya rendah. Karena mereka memiliki pengalaman dalam merespon variasi dan perubahan-perubahan stimulus yang diberikan. Pada gaya mengajar komando lebih cocok untuk terapi kesalahan gerakan teknik, hal ini disebabkan cara penyajian materi yang dikontrol secara ketat, mengikuti contoh yang diberikan oleh gurunya. Pendapat tersebut yang dikemukakan Mosston dan Ashworth (1994) bahwa gaya mengajar komando bertujuan mengarahkan siswa dalam melakukan tugas gerak secara akurat dan di dalam waktu yang singkat. Siswa harus mengikuti segala intruksi yang disampaikan oleh guru.

\section{SIMPULAN}

Berdasarkan hsil pengolahan data yang telah dilakukan, dapat ditarik kesimpulan sebagai berikut :

1. Gaya mengajar resiprokal lebih baik dari pada gaya mengajar komando terhapat hasil belajar keterampilan sepakbola

2. Terdapat interaksi antara gaya mengajar dan kemampuan awal terhadap hasil

belajar keterampilan sepakbola.

3. Gaya mengajar komando memberi penggaruh yang lebih baik terhadap hasil belajar keterampilan sepakbola pada siswa yang memiliki kemampuan awal tinggi.

Gaya mengajar resiprokal memberi penggaruh yang lebih baik terhadap hasil belajar keterampilan sepakbola pada siswa yang memiliki kemampuan awal rendah.

\section{DAFTAR PUSTAKA}

Arikunto, Suharsimi, (2002), Prosedur Penelitian; Suatu Pendekatan Praktek, Cetakan Ke XII, Jakarta: PT Rineka Cipta.

Adang Suherman. (1996). Pedagogi Olahraga. Bandung 1 FPOK IKIP Bandung.

Ali Maksum. (2012), Metodologi Penelitian Dalam Olahraga. Unesa University Press.

Fraenkel, JR,. Wallen, NE. (1993). How To Design and Evaluate Research in Education. USA: McGraw Hill, Inc.

Gifford, Clive, (2007), Keterampilan Sepak Bola, Yogyakarta, PT Citra Aji Parama.

Good, Thomas L., Brophy, Jere E., (1990), Educational Psychology A Realistic Approach, New York \& London : Longman.

Hyllegard, R. Et.al. (1996), Interpreting Research in Sports and Exercise Science St. Louise, Missouri : Mosby-Year Book Inc.

Harsono, (1988). Coaching Dan ApekAspek Psikologis Dalam Coaching, Jakarta, CV Tambak Kusuma.

Jumhana, J., \& Agustan, B. (2016). Pengaruh Model Directinstruction Terhadap Teknik Dasar Dribbling 
Dalam Permainan Sepak Bola. JUARA : Jurnal Olahraga, 1(1), 4650. Retrieved from http://jurnal.upmk.ac.id/index.php/ju ara/article/view/57

Joseph, Luxbacher (1997) Sepak Bola. Alih bahasa agusta wibawa. Pt. Raja gravindo persada.

Kamus Besar Bahasa Indonesia (1989).. Jakarta 1 Balai Pustaka ,1 Depdikbud

Mukholid, Agus (2007), Pendidikan Jasmani Olahraga \& Kesehatan, Surakarta : PT Ghalia Indonesia Printing.

Metzler, Michael W., (2000), instructional Models for Physical Education, Allyn and Bacon, A. Pearson Educational Company.

Mosston, Muska (1981), Teaching Physical Education, $2{ }^{\text {nd }}$ Edition, Colombus, Ohio: Charles E. Merril Publishing, A Bell \& Howell Co.

Mielke, Danny (2007), Dasar-Dasar Sepak Bola, Eastern Oregon University, PT. Intan Sejati.

Midgley Rud (2000), Ensiklopedi Olahraga, Semarang, Effhar Offset.

Nugraha, Adrian R (2010), Mengenal Aneka Cabang Olahraga, Bekasi, PT Cahaya Pustaka Raga.

Nurhasan. (2001). Tes dan Pengukuran dalam Pendidikan Jasmani. Jakarta: Depdiknas.

Nurhasan.Cholil (2007) Tes dan Pengukuran Keolahragaan. Fakultas Pendidikan Olahraga dan Kesehatan Universitas Pendidikan Indonesia Bandung.
Pratama, S., \& Hadiana, O. (2016). Pengaruh Model Cooperative Learning Terhadap Sikap Kerjasama Dan Hasil Belajar Sepakbola. JUARA : Jurnal Olahraga, 1(2), 94-99. Retrieved from http://jurnal.upmk.ac.id/index.php/ju ara/article/view/23

Ramadan, G. (2017). Pengaruh Metode Pembelajaran Dan Motivasi Belajar Terhadap Hasil Belajar Passing Sepakbola. JUARA : Jurnal Olahraga, 2(1), 1-10. Retrieved from http://jurnal.upmk.ac.id/index.php/ju ara/article/view/27

Sucipto, dkk (2000) Sepak Bola, Direktorat Jenderal Pendidikan Dasar dan Menengah, Bagian Proyek Penataran Guru SLTP Setrata D-III. Depdiknas.

Sudjana, (2002), Metode Statistika, Edisi ke 6, Bandung: Tarsito.

Sugiyono. (2010). Metode Penelitian Kuantitatif Kualitatif dan $R \& D$. Bandung: Alfabeta.

Schmidt, Richard A., (1991). Motor Leaming and Performance. From Principles to practice, Campaign,

Tinning, Richard, (1987), Improving Teaching in Physical Education, Deakin University, Australia; Brown Prior Anderson Pty.Ltd.

Universitas Pendidikan Indonesia (2013). Pedoman Karya Tulis Ilmiah. Bandung: UPI.

Vernon N. Crew, Measurment Concept in Physical Education St Louis : The C.V. Mosby Company.

Verducci, and Frank, M (1989). Measurment Concept in Physical Education.St Louis : The C.V. Mosby Company. 